Pobrane z czasopisma Annales N - Educatio Nova http://educatio.annales.umcs.pl Data: 26/04/2023 16:19:25

DOI: 10.17951/en.2018.3.143-155

\begin{tabular}{lcr}
\hline & ANNALES \\
& UNIVERSITATIS MARIAE CURIE-SKŁODOWSKA & \\
LOL. III & LUBLIN - POLONIA & 2018 \\
\hline
\end{tabular}

Katarzyna Skowronek

AGH w Krakowie

ORCID: https://orcid.org/0000-0003-0200-7217

kskowronek85@gmail.com

\title{
Udział Polek w przedwojennym językoznawstwie - rekonesans badawczy
}

\author{
Contribution of Polish Female Linguists \\ to Pre-War Linguistics - Scientific Review
}

Streszczenie: Tekst jest fragmentarycznym przedstawieniem sylwetek kobiecych, które współkształtowały polską lingwistykę przed 1939 rokiem. Autorka analizuje udział kobiet w Polskim Towarzystwie Językoznawczym i ich wkład w rozwój „Poradnika Językowego”, znaczącego czasopisma tego okresu. Artykuł ma charakter rekonesansowy - opisano możliwe ramy teoretyczne przyszłej herstorii polskiej lingwistyki.

Słowa kluczowe: polskie językoznawczynie przed 1939 rokiem; herstory; historia alternatywna; Polskie Towarzystwo Językoznawcze; „Poradnik Językowy”

\section{KOBIETY W NAUCE. UWAGI WSTĘPNE}

Tytuł niniejszego artykułu wskazuje na najważniejsze jego cele. Są one dwojakie. Po pierwsze, interesuje mnie krótki opis współuczestnictwa kobiet w tworzeniu polskiej myśli językoznawczej przed 1939 rokiem (m.in. badam ich obecność w polskich towarzystwach i czasopismach lingwistycznych tego 
czasu). Po drugie, chciałabym przedstawić ramę teoretyczną narracji, które określane są jako herstory (czy w spolszczonej wersji - herstoria) - w przekonaniu, że herstoria polskiej lingwistyki nie została jeszcze napisana, a byłaby to praca ważna i potrzebna. W tym tekście, o charakterze rekonsansowym, chcę pokazać tylko możliwości i kierunki takiej refleksji. Przy okazji zaznaczę, że nie traktuję kategorii „kobiecości w językoznawstwie” jako czegoś esencjonalnego, mającego swoją „twardą” definicję - nie jest to w moim ujęciu specyficzny styl myślenia, uprawiania nauki czy pisarstwa naukowego. Raczej pojmuję to zjawisko jako efekt działania pewnego typu zmiennych sił dyskursywnych, praktyk społecznych, historycznych i instytucjonalnych.

Obecnie modna staje się problematyka obecności/nieobecności (widoczności/niewidoczności) kobiet w historii nauki i próba rewizji tego zjawiska. Problem ten można rozpatrywać przynajmniej w trzech wymiarach:

- historyczno-biograficznym: „odkrycie” postaci kobiecych, które miały udział w rozwoju danej dziedziny wiedzy,

- socjologiczno-historycznym: płeć jako ważna zmienna w społecznej organizacji życia naukowego, w instytucjach naukowych itd.,

- kulturowym: płeć w nauce jako element przeświadczeń i stereotypów kulturowych, oddziałujący na życie naukowe.

Zainteresowanie społeczne tym tematem skupia się przede wszystkim na pierwszym z tych wątków i wzrasta każdorazowo m.in. za sprawą takich mainstreamowych filmów, jak Maria Skłodowska-Curie (reż. Marie Noelle, 2016) i Ukryte działania (reż. Theodore Melfi, 2016). Oba przedstawiają znaczący udział kilku kobiet w rozwoju nauk ścisłych w zdominowanym przez mężczyzn świecie dwudziestowiecznej nauki we Francji i w Stanach Zjednoczonych. Podobne zagadnienia pojawiają się w popularnonaukowych książkach, jak choćby Rachel Swaby Upór i przekora. 52 kobiety, które odmienity naukę $i$ świat ${ }^{1}$. Dyskurs medialny koncentruje się na wątkach spektakularnych i sensacyjnych, na kobietach-odkrywczyniach, których nazwiska zostały „przesłonięte” nazwiskami mężczyzn, na żonach wybitnych naukowców, co do których trwają spekulacje dotyczące ich rzeczywistego, lecz dotychczas przemilczanego współudziału w osiągnięciach naukowych ich mężów (casus Milevy Marić, pierwszej żony Alberta Einsteina²).

Dziennikarze upowszechniają również terminy „efekt Matyldy” i „efekt św. Mateusza" w nauce. Ten pierwszy polega na pomijania udziału kobiet-naukowców

1 R. Swaby, Upór i przekora. 52 kobiety, które odmienity naukę i świat, przeł. K. Kurek, Warszawa 2017.

2 Por. np. M. Benedict, Pani Einstein, przeł. N. Mętrak-Ruda, Kraków 2017. 
w odkryciach, pracach badawczych i przypisywaniu ich osiągnięć naukowcom-mężczyznom. Zjawisko to zostało opisane w 1993 roku przez Margaret W. Rossiter ${ }^{3}$, a jego nazwa nawiązuje do postaci amerykańskiej sufrażystki Matildy J. Gage. Pod koniec XIX wieku zwróciła ona uwagę na niedocenianie osiągnięć naukowych kobiet. Natomiast drugi termin dotyczy nadreprezentacji osiągnięć osób, które znajdują się na szczycie akademickiej hierarchii - wedle cytatu z Ewangelii „Każdemu bowiem, kto ma, będzie dodane, tak że nadmiar mieć będzie. Temu zaś, kto nie ma, zabiorą nawet to, co ma" (Mt 25,29).

Coraz więcej pojawia się tekstów publicystycznych i raportów dotyczących udziału kobiet w rozwoju dyscyplin naukowych. Przytaczane są wyniki eksperymentów z zakresu psychologii społecznej, na temat barier w komunikacji naukowej wynikających ze stereotypów płciowych (wyrażających się m.in. w preferencjach dotyczących cytowań tekstów naukowych, sposobów ich oceny przez recenzentów, liczby nagród naukowych, oceny kandydatów i kandydatek na stanowiska akademickie ze względu na kryterium płci, kwalifikacji danej osoby na podstawie jej wyglądu itd.). Dostępne są też wyniki raportów socjologicznych (tylko 26\% ankietowanych Polaków/Polek uważa kobiety za predysponowane do pracy $w$ nauce $)^{4}$. Ponadto do obiegowych wyrażeń należą takie określenia, jak „szklany sufit" (czyli niewidoczne przeszkody stojące na drodze awansu kobiet, które dostrzegają wyższe piętra zawodowe, ale są one dla nich nieosiągalne albo trudno osiągalne) i „lepka podłoga” (zjawisko polegające na przypisaniu kobiet do pewnej grupy ról i funkcji mniej prestiżowych i gorzej płatnych, zachodzi ono także w profesjach znaczących).

Do powszechnej wiedzy należy również problem udziału kobiet zatrudnionych w sektorze naukowo-akademickim w zachodnim kręgu cywilizacyjnym, który można nazwać efektem „zwężającego się leja, dziurawego rurociągu czy magicznego pudełka do znikania"5 - zjawisko to, choć ma wiele metaforycznych nazw, wyrazić można w ogólnej formule: „Im wyższe stanowisko, tym mniej kobiet". Dotyczy to zarówno uzyskiwanych stopni i tytułów naukowych,

3 Por. M.W. Rossiter, The Matthew Matilda Effect in Science, "Social Studies of Science" 1993, Vol. 23(2), s. 325-341; eadem, Women Scientists in America, Vol. 1: Struggles and strategies to 1940, Baltimore 1982 oraz pozostałe tomy tego dzieła, poświęcone obecności kobiet w amerykańskiej nauce od XIX wieku do współczesności.

4 Por. np. Badanie: świat nauki to męski świat, http://naukawpolsce.pap.pl/aktualnosci/news,409592,badanie-swiat-nauki-to-meski-swiat.html [dostęp: 20.05.2017]; Nie wyglada mi pani na naukowca. Jak kobiecość przeszkadza w karierze naukowej, www.crazynauka.pl/nie-wyglada-mi -pani-na-naukowca-jak-kobiecosc-przeszkadza-w-karierze-naukowej [dostęp: 20.05.2017].

5 Por. np. A.N. Pell, Fixing the Leaky Pipeline: Women Scientists in Academia, "Journal of Animal Science” 1996, Vol. 74(11), s. 2843-2848; M. Młodożeniec, A. Knapińska, Czy nauka wciąż ma męska pteć? Udziat kobiet w nauce, „Nauka” 2013, nr 2, s. 47-72. 
pozyskiwania grantów, jak i członkostwa w instytucjach naukowych. Wystarczy podać tylko dwa przykłady z polskiej rzeczywistości naukowej: w obecnej kadencji w skład Prezydium Polskiej Akademii Nauk wchodzi 26 osób, w tym dwie kobiety $(7,5 \%)^{6}$; podobnie jest w Prezydium Centralnej Komisji ds. Stopni i Tytułów - 11 osób, w tym jedna kobieta $(9 \%)^{7}$.

Przyczyn relatywnie mniejszego udziału kobiet w nauce poszukuje się m.in. w: formach socjalizacji; funkcjonujących stereotypach i dychotomiach kultury zachodnioeuropejskiej, dotyczących tego, co "męskie” i „żeńskie”; historycznych kontekstach współczesnej nauki. Ponadto podkreślana jest często obecna dziś idea równych szans w karierze akademickiej, neutralności nauki oraz niezależności dokonań od płci, wyrażanych w haśle „Nauka nie jest ani kobieca, ani męska, tylko dobrze lub źle uprawiana”. Wydaje się jednak, że deklarowane zasady niejako wyprzedzają rzeczywistość społeczną (przeczą im liczby i fakty, w tym te niektóre powyżej przytoczone); dodatkowo ten typ pojmowania nauki milcząco zakłada, że funkcjonuje ona w specyficznej „społecznej próżni”, w której czynniki ekonomiczne, polityczne, etniczne i płciowe są nieistotne.

$\mathrm{Z}$ drugiej strony w przestrzeni publicznej pojawia się wiele inicjatyw, które próbują w jakiś sposób nadrobić „historyczne zaszłości”. Są to projekty herstoryczne upowszechniające osiągnięcia kobiet m.in. w rozwoju nauki: Archiwum Historii Kobiet, Fundacja Przestrzeń Kobiet, Polska Sieć Kobiet Nauki, Sto Lat Głosu Kobiet. Powstają w związku z nimi rozmaite inicjatywy, typu Krakowski Szlak Kobiet, Przewodniczka po Krakowie emancypantek, Lubelskie szlaki herstoryczne czy Herstoryczki w Warszawie oraz programy stypendialne, np. „Dziewczyny do nauki” czy „Kobiety w nauce”, „Dziewczyny na Politechnikę”. Organizuje się też konferencje naukowe poświęcone temu zagadnieniu.

Wydaje się zatem, że problem na poziomie ogólnospołecznym może nie tyle jest rozwiązany, co przynajmniej już jest rozpoznawalny i stale diagnozowany. Mimo to warto podkreślić, że większość tych badań i interpelacji społecznych dotyczy przede wszystkim nauk ścisłych, przyrodniczych i inżynieryjnych, które dotąd uważane były za sfery „męskie”, z tego powodu jest na nich skupiona uwaga mediów i opinii publicznej.

Nauki humanistyczne wydają się być „rejonem” stereotypowo postrzeganym jako „domena kobiet”, w którym problem ich ewentualnej „niewidoczności” nie istnieje. Dane z 2012 roku pokazują względnie wyrównany poziom zatrudnienia

6 Prezydium Polskiej Akademii Nauk (kadencja 2015-2018), https://instytucja.pan.pl/index.php/wladze-pan?id=17 [dostęp: 20.05.2017].

7 Prezydium Centralnej Komisji ds. Stopni i Tytułów, www.ck.gov.pl/articles/id/7.html [dostęp: 20.05.2017]. 
w instytucjach humanistyki akademickiej (45\% kobiet, 55\% mężczyzn) ${ }^{8}$. Jednak informacje dotyczące płciowych proporcji w gremiach decyzyjnych pokazują obraz zgodny z ogólną wyżej zarysowaną tendencją - kobiety posiadają w nich (znacząco) niższy udział, niż wynikałoby to z ich zatrudnienia w tym sektorze. Dwa przykłady: Sekcja I Nauk Humanistycznych i Społecznych Centralnej Komisji ds. Stopni i Tytułów liczy 52 osoby, w tym 16 kobiet (30\%); Rada Kuratorów Wydziału I Nauk Humanistycznych i Społecznych PAN - 20 osób, w tym trzy kobiety $(15 \%)^{10}$.

Warto też spojrzeć na dyscyplinę już bliższą, czyli językoznawstwo. Tu też tylko trzy przykłady. Pierwszy to jeden z nowszych podręczników historii polskiego językoznawstwa z 2001 roku, o tyle ważny w międzynarodowym obiegu naukowym, że napisany w języku angielskim - w 12-osobowym gronie autorsko-redaktorskim jest jedna kobieta; wśród portretów sześciu osób znaczących dla rozwoju językoznawstwa polskiego - wyłącznie mężczyźni ${ }^{11}$. Podobne wnioski mogą się pojawić po lekturze Encyklopedii językoznawstwa ogólnego ${ }^{12}$. Zespół siedmiu autorów-mężczyzn; wśród licznych artykułów hasłowych dotyczących sylwetek osób mających zasługi dla językoznawstwa polskiego i światowego nie ma ani jednego poświęconego językoznawczyni. Brakuje tu dorobku światowych badaczek, pracujących m.in. w zakresie psycholingwistyki, językoznawstwa kognitywnego, socjolingwistyki, nauczania języka czy analiz dyskursu, jak Eleanor Rosch czy Robin Lakoff. Zamiast np. przedstawienia dorobku Marii Dłuskiej, znanego przecież nie tylko tym, którzy zajmują się fonetyką języka, jest sylwetka Friedricha Ch. Dieza - dziewiętnastowiecznego znawcy poezji trubadurów, kojarzonego zapewne tylko przez specjalistów. Istotna dla polskiej lingwistyki płci (i polskiej lingwistyki w ogóle) praca Małgorzaty Karwatowskiej i Jolanty Szpyry-Kozłowskiej z 2005 roku $^{13}$ nie wpłynęła zasadniczo na sposób formułowania naukowych sądów przez innych badaczy/badaczki. Dokonują oni/one często swoistej autocenzury myśli, uzasadniając swoje opinie „ostrożnie” i „neutralnie”"14.

8 Por. M. Młodożeniec, A. Knapińska, op. cit.

9 Sekcja I Nauk Humanistycznych i Społecznych Centralnej Komisji ds. Stopni i Tytułów, www.ck.gov.pl/articles/id/24.html [dostęp: 20.05.2017].

10 Rada Kuratorów Wydziału I Nauk Humanistycznych i Społecznych PAN, https://instytucja.pan.pl/index.php/wydzial-i [dostęp: 20.05.2017].

11 Towards a History of Linguistics in Poland. From the early beginnings to the end of the $20^{\text {th }}$ century, eds. E.F.K. Koerner, A. Szwedek, Amsterdam 2001.

12 Encyklopedia językoznawstwa ogólnego, red. K. Polański, Wrocław 1993.

13 M. Karwatowska, J. Szpyra-Kozłowska, Lingwistyka ptci. Ona i on w języku polskim, Lublin 2005.

14 Por. np. „Językoznawcy zajmują różne wobec tego zjawiska [asymetrii płciowej w języku] postawy - od całkowitego niedostrzegania lub/i pomijania tego problemu [...], poprzez podej- 


\section{KOBIETY W POLSKIM JĘZYKOZNAWSTWIE PRZED 1939 ROKIEM (NA PODSTAWIE ICH AKTYWNOŚCI W POLSKIM TOWARZYSTWIE JĘZYKOZNAWCZYM I „PORADNIKU JĘZYKOWYM”)}

Mamy zatem współcześnie sytuację analogiczną w stosunku do innych dziedzin, wymagającą pewnych refleksji, rewizji, zmiany perspektywy, reinterpretacji. A jaka jest wiedza współczesna dotycząca polskich przedwojennych językoznawczyń? Skupię się jedynie na kilku sylwetkach i faktach, które obejmują głównie okres przed 1939 rokiem.

Zacznijmy od znanego zdjęcia przedstawiającego członków walnego zebrania organizacyjnego Polskiego Towarzystwa Językoznawczego, z przewidzianą częścią naukową, które zwołano 31 maja 1925 roku we Lwowie ${ }^{15}$. Jan Baudouin de Courtenay w liście pisał: „Uczestnicy zjazdu fotografowali się zbiorowo w liczbie 23 członków i członkiń, ale to oczywiście nie świadczy ani za, ani przeciw użyteczności samego zjazdu"16. Z kolei Stanisław Urbańczyk w 1986 roku tak opisał fotografię:

Mimo zniszczeń wojennych ocalało kilka egzemplarzy fotografii, wykonanej we Lwowie w 1925 r. Przedstawia ona uczestników pierwszego zjazdu członków PTJ. W pierwszym rzędzie siedzą na krzesłach ówcześni koryfeusze, w środku patriarcha Jan Baudouin de Courtenay, bardzo już postarzały, obok Jan Rozwadowski z brodą opartą na wysokim sztywnym kołnierzyku, Jan Łoś, Kazimierz Nitsch, Stanisław Szober, Stanisław Witkowski, Andrzej Gawroński, Lehr-Spławiński z nich najmłodszy. Drugi rząd stoi w cieniu palm. Jest to młodzież, ówczesne 25-35 latki: Zenon Klemensiewicz, Henryk Osterreicher, Eugeniusz Słuszkiewicz, 25-letni Witold Doroszewski, Jan Otrębski, Henryk Gaertner. Wśród nich dwie młode panie, obie lwowianki: Maria Rytarowska i Janina Heydzianka. Twarze ich, niestety, zacienione kapeluszami. Profesor Pilatowa zmarła jako ostatnia ze wszystkich obecnych na zdjęciu ${ }^{17}$.

ście relacjonujące, które zajmuje się tą problematyką, pomijając jednak tło ideologiczne [...] - w ten nurt wpisuje się również niniejsza praca [podkr. - K.S.]". Zob. P. Pycia, Pteć a język na materiale wspótczesnego języka polskiego i chorwackiego, Katowice 2011, s. 14.

15 Por. http://ptj.civ.pl/pl/historia/czlonkowie-zalozyciele [dostęp: 20.05.2017].

16 M. Skarżyński, Powstanie Polskiego Towarzystwa Językoznawczego, „LingVaria” 2016, nr 2(22), s. 300; http://ptj.civ.pl/pl/historia/czlonkowie-zalozyciele [dostęp: 20.05.2017].

17 S. Urbańczyk, Wspomnienie: śp. Janina Heydzianka-Pilatowa, „Język Polski” 1987, nr 47(3-5), s. 161; Sp. Janina Heydzianka-Pilatowa (20 XI 1899 - 24 X 1986), www.tmjp.pl/ downloads/JaninaPilatowa.pdf [dostęp: 20.05.2017]. 


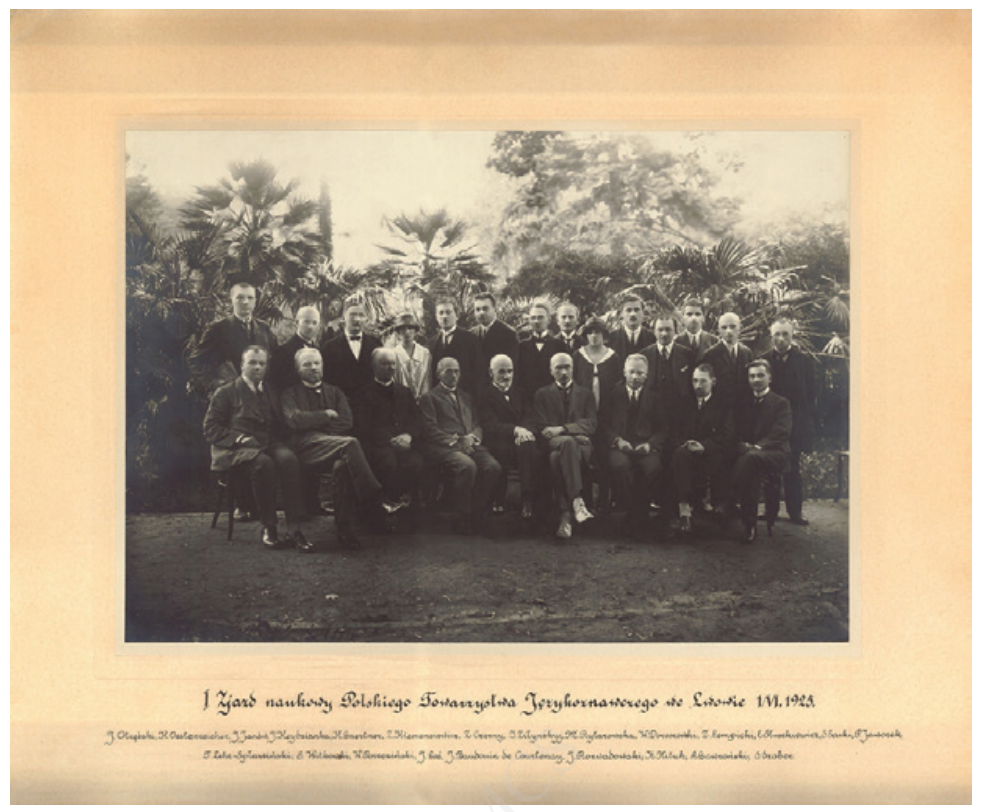

Kim więc były kobiety, których kapelusze osłaniały twarze w gronie 21 mężczyzn? Pierwsza z wymienionych, Maria Rytarowska, była polonistką, absolwentką Uniwersytetu Jana Kazimierza, nauczycielką i dyrektorką lwowskich gimnazjów, żoną indoeuropeisty profesora Eugeniusza Słuszkiewicza. Po wojnie pracowała naukowo na Uniwersytecie Mikołaja Kopernika w Toruniu w Katedrze Dydaktyki Języka i Literatury Polskiej. Autorka podręczników gramatyki języka polskiego i podręczników szkolnych ${ }^{18}$.

Janina Heydzianka-Pilatowa to polska językoznawczyni o różnorodnych zainteresowaniach. W roku powstania opisanej wyżej fotografii (1925) ukończyła studia na Wydziale Filologii Polskiej Uniwersytetu Lwowskiego, a dwa lata później (1927) obroniła doktorat. Przed wojną napisała wiele prac dotyczących języka połabskiego. Jak napisał Stanisław Urbańczyk, „obowiązki żony (w 1926 roku poślubiła Kazimierza Pilata, przyszłego profesora Politechniki Lwowskiej) i nauczycielki gimnazjalnej odciągnęły ją od pracy naukowej, tak że następny artykuł [...] ogłosiła dopiero w $1934 \mathrm{r}^{\prime \prime}{ }^{19}$. W tym samym roku została członkiem Komisji Językowej PAU. Do 1939 roku nauczycielka w gimnazjum we Lwowie, zaś od 1945 roku w Anglii - jako profesor Polskiego Uniwersytetu

18 www.pmkolekcja.pl/info,Eugeniusz_S\%C5\%82uszkiewicz.asp\#cite_ref-29 [dostęp: 20.05.2017].

19 S. Urbańczyk, op. cit., s. 162. 
na Obczyźnie (PUNO). Jako pierwsza z polskich badaczy zainteresowała się antropologią ukierunkowaną językoznawczo i pracami Bronisława Malinowskiego (w latach 50. opublikowała: Poglady B. Malinowskiego na role języka w kulturze, Problemy językowe w pracach Bronistawa Malinowskiego).

Już w 1926 roku liczba członków Polskiego Towarzystwa Językoznawczego powiększyła się ponad dwukrotnie (z 23 na 53 osoby). Na jego liście nadal były nazwiska tylko dwóch kobiet - obok wspomnianej już Marii Rytarowskiej pojawiła się postać (późniejszej) profesor Antoniny Obrębskiej-Jabłońskiej z Krakowa (1901-1994), później związanej z Warszawą i Uniwersytetem Warszawskim, językoznawczyni, polonistki i slawistki, twórczyni polskiej białorutenistyki. Warto podkreślić, że habilitację w 1934 roku otrzymała na Uniwersytecie Jagiellońskim jako jedna spośród zaledwie 15 kobiet przed wojną (jedynie Wydział Filozoficzny nie odmawiał kobietom prawa do habilitacji ${ }^{20}$. Po wojnie Antonina Obrębska była profesorem UW, kierowniczką Zakładu Filologii Białoruskiej, autorką prac z historii języka i dialektologiii ${ }^{21}$, tłumaczką i teoretyczką przekładoznawstwa, literaturoznawczynią, współredaktorką słowników i atlasów gwarowych.

W tym krótkim omówieniu dorobku polskich językoznawczyń przed II wojną światową należy także wskazać na ich udział w przedwojennej komunikacji naukowej, zapoznając się z ich artykułami umieszczanymi w specjalistycznych czasopismach. Tytułem rozpoznania wzięłam pod uwagę „Poradnik Językowy”, założony w 1901 roku przez Romana Zawilińskiego. Był to organ Towarzystwa Kultury Języka, jedno z najstarszych czasopism językoznawczych w Polsce. Ogląd wszystkich numerów od 1901 do 1939 roku² pod kątem partycypacji w nim kobiet przynosi następujące ustalenia.

Pierwszy tekst sygnowany nazwiskiem kobiety pojawił się w tym czasopiśmie dopiero w 1926 roku, czyli 25 lat po jego powstaniu. Jest to W sprawie stownictwa kucharskiego Jadwigi Wasilewskiej. Właściwie dopiero lata 1931 i 1932 stają się cezurą - od tego czasu nazwiska kobiet-autorek pojawiają się nieco częściej (np. Julii Wieleżyńskiej Sztuka - polskie umnictwo czy krasotwórstwo, Zofii Derwiszówny Jeszcze o formach typu wykonywam, wykonuję, wykonywuje, Irmy Kryńskiej-Polakiewiczowej O przekładach dziet obcych na język polski, Marii Załuskiej Zestawienie pojęć sprzecznych w języku i inne).

20 Por. U. Perkowska, Kobiety na Uniwersytecie Jagiellońskim, https://forumakademickie.pl/ fa-archiwum/archiwum/99/7-8/artykuly/kobiety_na_uj.htm [dostęp: 20.05.2017].

21 Zob. np. „Stryj, wuj, swak” w dialektach $i$ historii języka polskiego. Z 3 mapami, Kraków 1929.

22 Por. https://poradnik-jezykowy.uw.edu.pl/issues [dostęp: 20.05.2017]. 
Od 1933 roku w „Poradniku Językowym” ukazuje się seria tekstów Haliny Konecznej, z domu Świderskiej (1899-1961) (Przysłówki w funkcji przymiotników, O mieszaniu się niektórych form w języku, Wyrazy angielskie w języku polskim, Parę uwag o mazurzeniu). Halina Koneczna jeszcze przed wojną, w 1934 roku, habilitowała się na podstawie pracy Studium eksperymentalne artykulacji gtosek polskich. Po wojnie - jako profesor UW - zajmowała się dialektologia i historią języka, była jedną z inicjatorek powstania Stownika Języka Polskiego XVII i 1. połowy XVIII wieku.

Twórczość wszystkich przywołanych tu autorek to tylko znikoma część tekstów opublikowanych w „Poradniku Językowym” przez prawie 40 przedwojennych lat.

Ten krótki przegląd sylwetek kobiecych można byłoby oczywiście powiększyć m.in. o postacie Salomei Szlifersztejnowej (1912-1994) czy Cezarii Baudouin de Courtenay Ehrenkreutz-Jedrzejewiczowej (1885-1967) ${ }^{23}$, która jako pierwsza kobieta w Polsce w 1929 roku otrzymała nominację profesorską. Opis jej wybitnych dokonań pojawia się zwykle w związku z etnografią i badaniami nad folklorem, choć do tych dziedzin podchodziła ona z punktu widzenia "filologiczno-historycznego i językoznawczego", o czym świadczą m.in. jej prace przedwojenne (np. Jezzk modlitewnika maryjnego, wieku XVI wydanego przez prof. Ptaszyckiego, Św. Cecylia - przyczynek do genezy apokryfów).

\section{ZAKOŃCZENIE}

Ta migawkowa retrospektywa dotycząca udziału kobiet w przedwojennym językoznawstwie pokazuje jednak ich nieznaczną, w sensie systemowo-instytucjonalnym, obecność. Jest to efekt wielu praktyk formalnych i nieformalnych w świecie polskiej nauki, które miały silnie dyskryminacyjny charakter wobec kobiet. Wystarczy przypomnieć znany w historii polskiej nauki fakt, że w 1904 roku Senat UJ podjął negatywną decyzję dotyczącą habilitacji kobiet (mimo liberalnego stanowiska władz austriackich). $Z$ drugiej strony wyraźnie jest widoczny pewien element „nacisku” kobiet-językoznawczyń na struktury akademickie, próby zaznaczenia własnej obecności w „męskim świecie”. Z całą pewnością temat ten wymaga znacznie szerszych i staranniejszych analiz, które dokładnie pokazałyby wkład intelektualny kobiet w polskie językoznawstwo przedwojenne (i nie tylko). Taka herstoria lingwistyki stałaby się odpowiednim „kontrapunktem”, historią alternatywną dla powszechnie obowiązującej „męskiej historii” tej dziedziny humanistyki.

23 Por.www.heltechnic.pl/info_Cezaria_Baudouin_de_Courtenay_Ehrenkreutz_J\%C4\%99 drzejewiczowa [dostęp: 20.05.2017]. 
Powyższy przegląd pozwala poczynić pewne uwagi teoretyczne dotyczące idei badania zmiennej płciowej w praktykach naukowych jako pewnego typu refleksji w filozofii i historii nauk. Czym jest zatem herstory? „Adele Aldridge zaproponowała dekonstrukcję samego słowa »history«, zastępując męski przedrostek his, pierwszoosobowym $m y$, w efekcie czego, dzięki grze słów »mystory« $\mathrm{i} »$ mystery«, [...] przeszłość kobiet mogła stać się przedmiotem naukowych badań"24. His-story wskazuje, że historia jest jego opowieścią, sugeruje "męskość" tej dyscypliny; my - moją własną. My-story, czy też her-story, ten językowy, choć niezgodny z etymologią, zabieg stał się symboliczną nazwą historii pisanej z perspektywy kobiet lub przez feminizujące historyczki. Ta „heretycka historia” obejmuje np. dzieje aktywności kobiet, ewolucję ról społecznych, przeobrażenia mentalności kobiet, ich pisarstwa ${ }^{25}$.

Badania herstoryczne odbywają się na poziome ogólnym (zrozumienie pewnych procesów w nauce i jej historii z perspektywy płci) oraz biograficznym (jak np. kontekst społeczno-instytucjonalny wpływa na trajektorie losów badaczy/badaczek). Dominuje perspektywa interdyscyplinarna; wykorzystuje się różnorodne źródła (zarówno te konwencjonalne, jak i artefakty codzienności). Chodzi w tego typu pisarstwie o podmiotowe przedstawianie kobiet w tekście oraz o zachowanie pewnego typu wrażliwości genderowej (kulturowo-społeczne uwarunkowania płci) i społecznej (wielokulturowość, klasowość, status społeczno-ekonomiczny itd.) ${ }^{26}$.

Jak sądzę, badania dotyczące udziału kobiet w językoznawstwie polskim i europejskim powinny istnieć w ramie teoretycznej, wywodzącej się z trzech różnych zakresowo dziedzin.

Pierwsza z nich dotyczy nieklasycznych koncepcji historii nauk i pisania historii jakichś dziedzin ${ }^{27}$. Określane są one czasem mianem „historia alternatywna” czy „niekonwencjonalna” i są pojmowane jako przykłady niestandardowej refleksji nad historią, przy zrozumieniu wielu jej ograniczeń, wynikających choćby z zawężonej perspektywy. Dotychczasowa koncentracja na tym, co oficjalne,

24 „Thus as poetically expressed by Adele Aldridge: His story [became] History [and] My [women's] story [remained] Mystery", cyt. za: I. Milojević, Timing feminism, feminising time, "Futures" 2008, Vol. 40, www.researchgate.net/publication/239781566_Timing_feminism_feminising_time [dostęp: 20.05.2017], s. 329-345.

25 Por. E. Domańska, Historia feminizmu i feministyczna historia, „Odra” 1994, nr 7/8, s. 26.

26 Por. A. Derra, Kobiety (w) nauce. Problem ptci we wspótczesnej filozofii nauki i w praktyce badawczej, Warszawa 2013. Por. także: M. Kwiatkowska, A. Urbańczyk, E. Okroy, E. Okroy, A. Włodarczyk, Jak pisać teksty herstoryczne, http://metropolitanka.ikm.gda.pl/czytelnia/artykuly/ jak-pisac-teksty-herstoryczne [dostęp: 20.05.2017].

27 E. Domańska, Historie niekonwencjonalne. Refleksja o przeszłości w nowej humanistyce, Poznań 2006. 
publiczne, widoczne, zostaje tu zastąpiona przez koncentrację na subiektywnych doświadczeniach, na biografiach, na osobistej perspektywie badacza czy badaczki. Chodzi więc o pisanie historii - jak to określa Ewa Domańska - „insurekcyjnej i interwencyjnej, stanowiącej rodzaj krytyki dominującej kultury i zarazem noszącej w sobie pewien jej projekt" ${ }^{\prime 28}$. W obszar tematów poddanych takiemu opisowi i analizie włączono historię zagadnień istotnych dla życia społecznego, dotychczas marginalizowanych.

Druga dziedzina mieściłaby się w polu socjologii wiedzy, która zakłada, że nauka istnieje jako element większej kulturowej całości, a zatem mocno jest ograniczana czynnikami psychospołecznymi, ekonomicznymi, instytucjonalnymi, wreszcie wynikającymi z samych osobowości badaczy, ich postaw, ideologicznego zaplecza itd. ${ }^{29}$ Płeć jest ważną kategorią dotyczącą wszelkich relacji społecznych, także nauki. W socjologii wiedzy zwraca się uwagę nie tylko na obecność/nieobecność kobiet w rozwoju nauki, ale i na konstruowanie teorii naukowych dotyczących płci, podejmowane przez badaczy/badaczki tematy, praktyki instytucjonalne, rezultaty badawcze. Zakłada się, że płeć jest kategorią teoretyczną, która reguluje relacje społeczne w kontekście nauki, ale oczywiście ma swój empiryczny wyraz w konkretnych historycznych działaniach.

Trzecie pole koncepcyjne to socjologia krytyczna, która projektuje badania społeczne diagnozujące stan rzeczy i - jeśli jest on niezadowalający - możliwości jego przezwyciężenia ${ }^{30}$. Pokazuje pole nauki jako efekt przemian, konfliktów i sprzeczności, które mają charakter historyczny i współczesny. Istotne jest tu wskazanie problemów, które mają charakter strukturalny, publiczny i wymagają zmian systemowych, ale również wskazanie elementów emancypacyjnych. W ramach socjologii krytycznej pojawia się też feminizm jako zróżnicowany i heterogeniczny typ idei i teorii, mający charakter krytyczny wobec danego stanu rzeczy, interwencyjny i zdążający do zmiany społecznych praktyk na rzecz kobiet.

Połączenie tych trzech ujęć teoretycznych pozwoli na właściwą interpretację faktów biograficznych i dokonań naukowych kobiet w polskim językoznawstwie.

\footnotetext{
28 Ibidem, s. 19.

29 Por. A. Zybertowicz, Konstruktywizm jako orientacja metodologiczna w badaniach spotecznych, www.kulturaihistoria.umcs.lublin.pl/archives/48 [dostęp: 20.05.2017].

30 Por. J. Mucha, Socjologia jako krytyka spoteczna. Orientacja radykalna i krytyczna we wspótczesnej socjologii zachodniej, Warszawa 1986.
} 


\section{BIBLIOGRAFIA}

Badanie: świat nauki to męski świat, http://naukawpolsce.pap.pl/aktualnosci/news,409592,badanie-swiat-nauki-to-meski-swiat.html [dostęp: 20.05.2017].

Benedict M., Pani Einstein, przeł. N. Mętrak-Ruda, Kraków 2017.

Derra A., Kobiety (w) nauce. Problem ptci we wspótczesnej filozofii nauki i w praktyce badawczej, Warszawa 2013.

Domańska E., Historia feminizmu i feministyczna historia, „Odra” 1994, nr 7/8.

Domańska E., Historie niekonwencjonalne. Refleksja o przeszłości w nowej humanistyce, Poznań 2006.

Encyklopedia jezykoznawstwa ogólnego, red. K. Polański, Wrocław 1993. http://ptj.civ.pl/pl/historia/czlonkowie-zalozyciele [dostęp: 20.05.2017]. https://poradnik-jezykowy.uw.edu.pl/issues [dostęp: 20.05.2017].

Karwatowska M., Szpyra-Kozłowska J., Lingwistyka ptci. Ona i on w języku polskim, Lublin 2005.

Kwiatkowska M., Urbańczyk A., Okroy E., Okroy E., Włodarczyk A., Jak pisać teksty herstoryczne, http://metropolitanka.ikm.gda.pl/czytelnia/artykuly/jak-pisac-teksty -herstoryczne [dostęp: 20.05.2017].

Milojević I., Timing feminism, feminising time, "Futures" 2008, Vol. 40, www.researchgate.net/publication/239781566_Timing_feminism_feminising_time [dostęp: 20.05.2017].

Młodożeniec M., Knapińska A., Czy nauka wciąż ma męska pteć? Udział kobiet w nauce, „Nauka” 2013, nr 2.

Mucha J., Socjologia jako krytyka spoteczna. Orientacja radykalna i krytyczna we wspótczesnej socjologii zachodniej, Warszawa 1986.

Nie wyglada mi pani na naukowca. Jak kobiecość przeszkadza w karierze naukowej, www.crazynauka.pl/nie-wyglada-mi-pani-na-naukowca-jak-kobiecosc-przeszkadza-w-karierze-naukowej [dostęp: 20.05.2017].

Pell A.N., Fixing the Leaky Pipeline: Women Scientists in Academia, "Journal of Animal Science" 1996, Vol. 74(11).

Perkowska U., Kobiety na Uniwersytecie Jagiellońskim, https://forumakademickie.pl/ fa-archiwum/archiwum/99/7-8/artykuly/kobiety_na_uj.htm [dostęp: 20.05.2017].

Prezydium Centralnej Komisji ds. Stopni i Tytułów, www.ck.gov.pl/articles/id/7.html [dostęp: 20.05.2017].

Prezydium Polskiej Akademii Nauk (kadencja 2015-2018), https://instytucja.pan.pl/ index.php/wladze-pan?id=17 [dostęp: 20.05.2017].

Pycia P., Płeć a język na materiale wspótczesnego języka polskiego i chorwackiego, Katowice 2011.

Rada Kuratorów Wydziału I Nauk Humanistycznych i Społecznych PAN, https://instytucja.pan.pl/index.php/wydzial-i [dostęp: 20.05.2017].

Rossiter M.W., The Matthew Matilda Effect in Science, "Social Studies of Science" 1993, Vol. 23(2).

Rossiter M.W., Women Scientists in America, Vol. 1: Struggles and strategies to 1940, Baltimore 1982. 
Sekcja I Nauk Humanistycznych i Społecznych Centralnej Komisji ds. Stopni i Tytułów, www.ck.gov.pl/articles/id/24.html [dostęp: 20.05.2017].

Skarżyński M., Powstanie Polskiego Towarzystwa Językoznawczego, „LingVaria” 2016, nr 2(22).

„Stryj, wuj, swak” w dialektach i historii języka polskiego. Z 3 mapami, Kraków 1929.

Swaby R., Upór i przekora. 52 kobiety, które odmienity nauke i świat, przeł. K. Kurek, Warszawa 2017.

Śp. Janina Heydzianka-Pilatowa (20 XI 1899 - 24 X 1986), www.tmjp.pl/downloads/ JaninaPilatowa.pdf [dostęp: 20.05.2017].

Towards a History of Linguistics in Poland. From the early beginnings to the end of the $20^{\text {th }}$ century, eds. E.F.K. Koerner, A. Szwedek, Amsterdam 2001.

Urbańczyk S., Wspomnienie: śp. Janina Heydzianka-Pilatowa, „Język Polski” 1987, nr 47(3-5).

www.heltechnic.pl/info_Cezaria_Baudouin_de_Courtenay_Ehrenkreutz_J\%C4\%99drze jewiczowa [dostęp: 20.05.2017].

www.pmkolekcja.pl/info,Eugeniusz_S\%C5\%82uszkiewicz.asp\#cite_ref-29 [dostęp: 20.05.2017].

Zybertowicz A., Konstruktywizm jako orientacja metodologiczna w badaniach spotecznych, www.kulturaihistoria.umcs.lublin.pl/archives/48 [dostęp: 20.05.2017].

Summary: The article is a partial presentation of women who helped shape the Polish linguistics before 1939. The author analyses their contribution in the Polish Linguistic Society and their influence on the development of the "Poradnik Językowy", an important journal of that period. The article is an overview: the author also describes the possible theoretical framework of the future "her-story" of Polish linguistics.

Keywords: pre-war Polish female linguists; her-story; alternative history; the Polish Linguistic Society; "Poradnik Językowy" 